\title{
The efficacy and safety of core decompression for the treatment of femoral head necrosis: a systematic review and meta-analysis
}

Kun-chi Hua ${ }^{1}$, Xiong-gang Yang ${ }^{2}$, Jiang-tao Feng², Feng Wang ${ }^{2}$, Li Yang ${ }^{2}$, Hao Zhang ${ }^{2}$ and Yong-cheng Hu ${ }^{1 *}$ (I)

\begin{abstract}
Background: Core decompression (CD) is an important method for the treatment of osteonecrosis of the femoral head $(\mathrm{ONFH})$. Few articles investigate the influence of core decompression on outcomes of ONFH. This study was carried out to observe the safety and effectiveness of core decompression in the treatment of ONFH.

Methods: A comprehensive literature search of databases including PubMed, Embase, and Cochrane Library was performed to collect the related studies. The medical subject headings used were "femur head necrosis" and "Core decompression." The relevant words in title or abstract included but not limited to "Osteonecrosis of the Femoral Head," "femoral head necrosis," "avascular necrosis of femoral head," and "ischemic necrosis of femoral head." The methodological index for nonrandomized studies was adopted for assessing the studies included in this review.
\end{abstract}

Results: Thirty-two studies included 1865 patients (2441 hips). Twenty-one studies (1301 hips) using Ficat staging standard, 7 studies (338hips) using Association Research Circulation Osseous (ARCO) staging standard, and University of Pennsylvania system for staging avascular necrosis (UPSS) staging criteria for 4 studies (802 hips). All the studies recorded the treatment, 22 studies (1379 hips) were treated with core decompression (CD) alone, and 7 studies (565 hips) were treated with core decompression combined with autologous bone (CD Autologous bone). Nine subjects (497 hips) were treated with core decompression combined with autologous bone marrow (CD Marrow). Twenty-seven studies (2120 hips) documented the number of conversion to total hip replacement (THA), and 26 studies (1752hips) documented the number of radiographic progression (RP). Twenty-one studies recorded the types of complications and the number of cases, a total of 69 cases. The random-effect model was used for meta-analysis, and the results showed that the overall success rate was $65 \%$. The rate of success showed significant difference on the outcomes of different stages. The rate of success, conversion to THA, and radiographic progression showed significant difference on the outcomes of ONFH using different treatments.

Conclusions: Core decompression is an effective and safe method of treating ONFH. The combined use of autologous bone or bone marrow can increase the success rate. For advanced femoral head necrosis, the use of CD should be cautious. High-quality randomized controlled trials and prospective studies will be necessary to clarify the effects of different etiology factors, treatments, and postoperative rehabilitation. Until then, the surgeon can choose core decompression to treat ONFH depending on the patient's condition.

Level of evidence: I Meta-analysis

Keywords: Core decompression, Femoral head necrosis, Meta-analysis

\footnotetext{
* Correspondence: huycdoctor@163.com

'Department of Orthopedic Oncology, Tianjin Hospital, Tianjin 300211, China

Full list of author information is available at the end of the article
}

(c) The Author(s). 2019 Open Access This article is distributed under the terms of the Creative Commons Attribution 4.0 International License (http://creativecommons.org/licenses/by/4.0/), which permits unrestricted use, distribution, and reproduction in any medium, provided you give appropriate credit to the original author(s) and the source, provide a link to the Creative Commons license, and indicate if changes were made. The Creative Commons Public Domain Dedication waiver (http://creativecommons.org/publicdomain/zero/1.0/) applies to the data made available in this article, unless otherwise stated. 


\section{Introduction}

Osteonecrosis of the femoral head (ONFH) is interrupted or damaged by the blood supply to the femoral head, causing death and subsequent repair of bone cells and bone marrow components, which in turn leads to structural changes in the femoral head and collapse of the femoral head, causing joint pain and dysfunction in patients, and the disease is difficult to heal [1-3]. High disability rate is a common refractory disease in the field of orthopedics. There is a lack of effective treatment in clinical practice [4]. Most patients have to undergo total hip arthroplasty. The search for minimally invasive, safe, and effective treatment of femoral head necrosis has been a hot topic in orthopedic research [5]. Core decompression (CD) reduces the pressure in the bone, opens up the hardening zone that hinders the repair of osteonecrosis, stimulates the formation of blood vessels around the decompression tunnel, enhances the replacement of the new bone, and delays the progression of osteonecrosis [2-5]. A study confirms that $\mathrm{CD}$ combined with cytotherapy is a relatively good treatment for reducing the failure rate of early and mid-term ONFH patients [6]. Another study confirmed that CD combined with autologous bone marrow stem cells has achieved good results in early ONFH patients [7]. The purpose of this study was to summarize the efficacy of core decompression in the treatment of ONFH, to analyze the factors affecting the core decompression treatment of $\mathrm{ONFH}$, and to evaluate the difference between the current core decompression and combined autologous bone or bone marrow therapy. Provide some useful advice for surgeons using core decompression therapy for ONFH.

\section{Materials and methods Literature search}

PubMed-MEDLINE and Ovid-Embase were adopted for the comprehensive literature searches using a combination of the medical subject headings and relevant words in the title or abstract. The medical subject headings used were "core decompression" and "femur head necrosis." The relevant words in the title or abstract included "femoral head necrosis," "avascular necrosis of femoral head," "ischemic necrosis of femoral head," and "Osteonecrosis of the femoral head." A cross-reference search was performed to identify additional studies. The search time is from January 1, 1980, to March 31, 2019, and the language is limited to Chinese and English. All retrieved records were added to an EndNote (Version X7; Thomson Reuters, New York, NY) library.

\section{Inclusion criteria}

The inclusion criteria are as follows:

1. The published core decompression treatment of femoral head necrosis; the average follow-up time $\geq 1$ year; the patient's basic information (age at the time of treatment, gender, history of previous hip disease, etc.) record is complete; and if there is a control group, the two groups of patients are required to have no significant differences in basic information (age at the time of treatment, gender, history of previous hip disease, etc.).

2. Patients with femoral head necrosis were diagnosed by clinical physical examination and imaging and required to be treated with core decompression.

3. All of the studies are core decompression treatment of femoral head necrosis, and patients undergo treatment to promote healing of the surgical site.

4. The main indicators of each study were number of successful operations, radiographic progression, complications, and secondary operations.

\section{Exclusion criteria}

The exclusion criteria are as follows:

1. The studies that were not associated with core decompression for femoral head necrosis

2. The number of successful hips after core decompression therapy was not clearly recorded, or a clear definition of surgical success was not given.

3. No analysis of prognostic factors

4. Review, case report, meetings abstracts, animal studies, editorial letters, guidance or comments, etc.

5. Repeated studies

6. Lower literature quality scores

\section{Quality assessment}

The case series study used the National Institute for Clinical Excellence (NICE) case series scoring standard for quality evaluation. The case-control study used the NewcastleOttawa Scale (NOS) for quality evaluation. The scale was divided into three parts: "selection," "comparability," and "exposure." The random control trial (RCT) used a modified Jadad scale for quality assessment, including randomized mass, grouped concealment, double-blind, and sample outcomes. Two researchers independently conducted a rigorous quality evaluation of the retrieved literature in accordance with the above inclusion and exclusion criteria. When there were different opinions, the discussion was conducted and a third researcher was invited to participate in the review.

\section{Data extraction}

Relevant information, including first author, year of publication, study design, country of study, total number and age of ONFH patients, use of autologous bone or bone marrow during surgery, and preoperative and postoperative hip staging and criteria, was extracted. The clinical outcomes of our study included overall surgical 
success rate (definition of successful surgery: during follow-up, Harris hip score (HHS) $\geq 70$, no further THA surgery required, no radiographic progression), rate of conversion to THA, rate of radiographic progression, rate of success in different stages, and complications such as fracture, surgical site pain, hematoma, deep vein thrombosis, and infection.

\section{Statistical analysis}

Descriptive analysis of indicators that cannot be combined or that are not suitable for consolidation. In our study, we used the extracted raw data to calculate the rate of conversion to THA, the rate of radiological progression, the success rate of different treatment methods, and the success rate of different stages in each study. According to the sample size corresponding to each group rate, the corresponding standard deviation is calculated, and the standard deviation of the rate and rate is used as the effect amount for metaanalysis. $X^{2}$ test was used for quantification of statistical inconsistency between studies, and $I^{2}$ values showed the degree of heterogeneity. When significant heterogeneity $(P \leq$ 0.1 and $I^{2} \geq 50 \%$ ) was detected, studies were combined using a random-effects model. When no significant heterogeneity $\left(P>0.1\right.$ and $\left.I^{2}<50 \%\right)$ was detected, studies were combined using a fixed-effects model. The differences between subgroups were further tested, and a value of $P$ less than 0.05 was considered statistically significant.

The $X^{2}$ test was used to compare the success rate of Ficat I, II, and III stage, the success rate of different treatment methods, the rate of conversion to THA of different treatment methods, and the radiographic progression rate of different treatment methods. The test level $\alpha$ value was 0.05 . The process was statistically analyzed using the SPSS 20.0 statistical software package.

\section{Results}

\section{Literature search}

A flow diagram explaining the literature search strategy and study selection is shown in Fig. 1. A total of 917 articles were found by computer search, of which 384 were PubMed and 533 were retrieved from Embase (Additional file 1). Through the check processing of EndNote software, it was found that 509 articles were duplicated, and the remaining 408 articles of the title and abstract deletion of the literature were not in conformity with the remaining 63 articles after inclusion of the exclusion criteria. In order to further screen the full text of the reading, the remaining 32 studies were reproduced and the quality was completed. The evaluation included 3 RCTs [8-10], 26 case series studies [5, 11-35], and 3 case-control studies [36-38].

\section{Study characteristics}

The basic characteristics of those studies are shown in Table 1 . The study included 1865 patients (2441 hips) with an average age of approximately 37.72 (12-85) years, a female ratio of approximately $35.57 \%$, and an average follow-up of 54.3 (2-228) months. The 32 studies included 3 RCTs, 26 case series studies, and 3 casecontrol studies. The RCT study used a modified version of the Jadad scale for quality evaluation, the average score of the three RCT studies was 5.67. The 26 case series used the NICE case series scoring criteria for quality evaluation, the average score of the study was 5.88 . Three case-control studies used NOS scales for quality assessment with an average score of 8.67.

\section{Clinical outcomes}

Clinical outcomes of included studies are shown in Table 2. Meta-analysis using a random-effects model due to heterogeneity showed an overall effect size (ES) of 0.65 (95\% CI $(0.60,0.70)$ ) (Fig. 2), as shown in the published core decompression treatment of the femoral head necrosis. In the literature, the overall success rate after surgery was $65 \%$.

A total of 29 studies [5, 8, 10, 12-26, 28-38] (2095 hips) recorded the etiologic factors and the number of hips. The most common etiologic factor was steroids (894 hips, 42.7\%), followed by alcohol (584 hips, 27.9\%) and idiopathic (299 hips, 14.3\%). The specific etiologic factors and number of hips are shown in Fig. 3.

A total of 21 studies $[8,10,12,14-16,18-20,22-26$, $29,30,33,34,36-38]$ (1440 hips) recorded the type of complications and the number of cases, a total of 69 hips (4.79\% 69/1440). Common complications are heterotopic ossifications (23 hips, 33.3\%), pain (15 hips, 21.7\%), and fracture (13 hips, 18.8\%), and the specific complications and the number of hips are shown in Table 2.

We pooled analyses on the overall success rate; success rate of Ficat I, II, and III stage; the success rate of different treatment methods; the rate of conversion to THA of different treatment methods; and the radiographic progression rate of different treatment methods were conducted based on the data from the 32 studies.

\section{Success rate of different stages}

All studies recorded the staging of preoperative femoral head necrosis. Of these, 21 studies $[12-25,27,30,31$, 33, 34, 36, 38] (1301 hips) used Ficat staging criteria, 17 studies [12, 13, 15-25, 30, 31, 34, 36] included stage I cases, 21 studies $[12-25,27,30,31,33,34,36,38]$ included stage II cases, 16 studies [12-16, 18, 20, 21, 23$25,27,30,31,33,34]$ included stage III cases, and only one study included stage IV cases; 7 studies [8-10, 28, 32, 35, 37] (338 hips) used the Association Research Circulation Osseous (ARCO) staging criteria, 6 studies [8, 


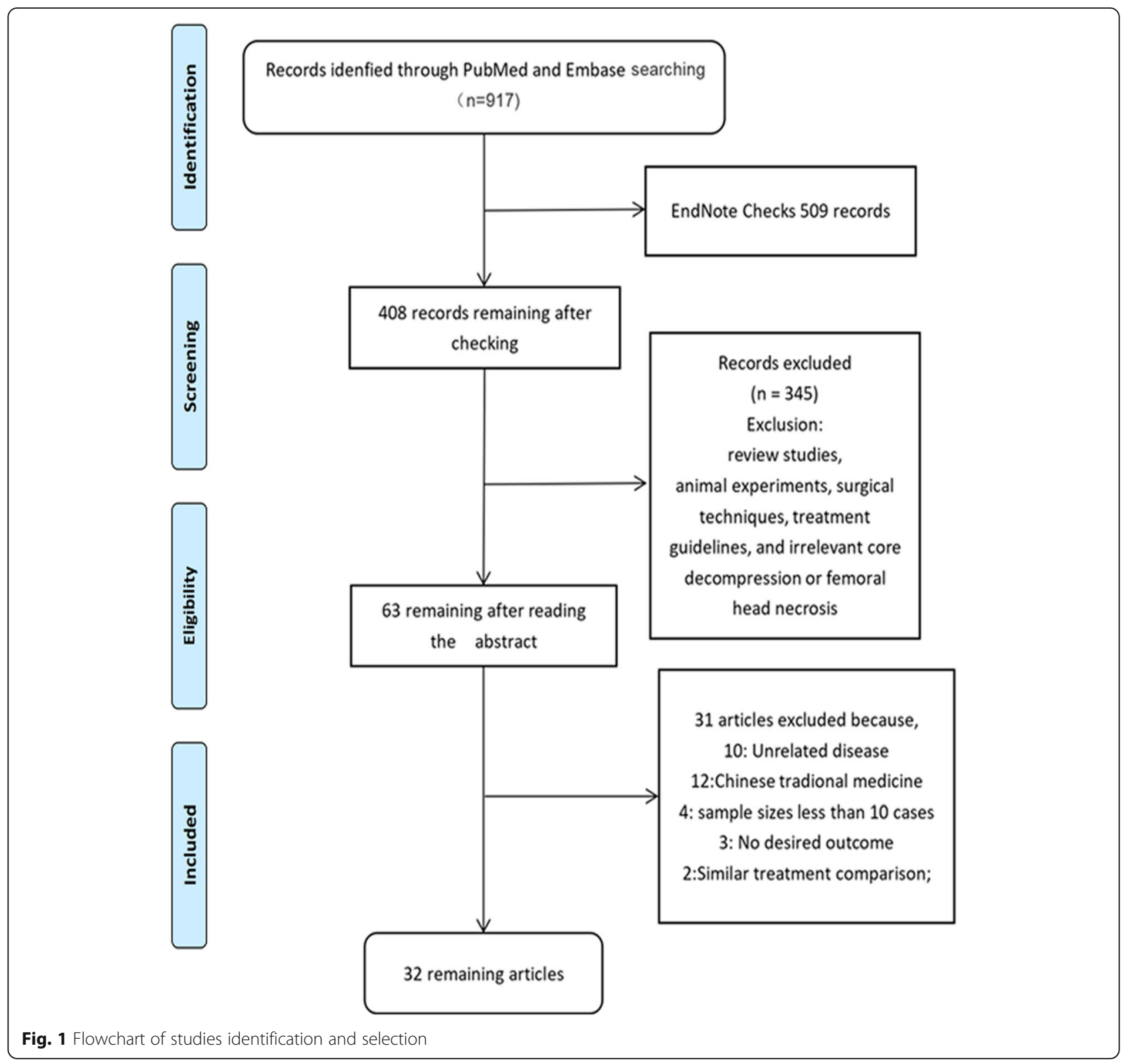

$10,28,32,35,37]$ included stage I cases, and 7 [8-10, $28,32,35,37]$ studies included stage II cases, and 2 studies $[28,35]$ included stage III cases; 4 studies $[5,11$, 26, 29] (802 hips) used the University of Pennsylvania system for staging avascular necrosis (UPSS) staging criteria, 4 studies $[5,11,26,29]$ included stage I cases, 4 studies [5, 11, 26, 29] included stage II cases, 3 studies $[5,11,26]$ included stage III cases, and 2 studies $[5,11]$ included stage IV cases (Fig. 4).

Considering the impact of the study and the number of cases on the outcome, this article only compares the success rates of Ficat I (220/280 78.29\%), II (383/645 59.38\%), and III (59/215 27.44\%). Statistical analysis showed that the success rate of Ficat I (220/280 78.29\%) > II (383/645 59.38\%) $>$ III (59/215 27.44\%), the difference is statistically significant
$\left(X^{2}=130.435, P<0.05\right)$. Ficat I success rate and Ficat II success rate, the difference is statistically significant $\left(X^{2}=\right.$ $30.820, P<0.05)$, Ficat II success rate and Ficat III success rate, the difference was statistically significant $\left(X^{2}=65.844\right.$, $P<0.05$ ), Ficat I success rate and Fica III success rate, the difference is statistically significant $\left(X^{2}=127.980, P<0.05\right)$.

\section{Success rate of different treatments}

Treatment was documented in all studies, 22 studies [8$12,15,17-25,29,31,33,34,36-38]$ (1379 hips) with core decompression (CD), and 5 studies $[5,27,28,36$, 38] (565 hips) with core decompression and autologous bone (CD+A.B); 9 studies [8-10, 13, 14, 16, 26, 35, 37] (497 hips) used core decompression in combination with autologous bone marrow (CD+Marrow). 
Table 1 Basic characteristics of included studies

\begin{tabular}{|c|c|c|c|c|c|c|c|c|c|}
\hline Author & Year & Study type & Nation & Male/female & Age & Hips & Therapies & Evaluation standard & Study quality \\
\hline Gangji & 2011 & $\mathrm{RCT}$ & Belgium & $9 / 10$ & 43.86 & 24 & $\begin{array}{l}\text { Control: CD } \\
\text { Trial: } C D+\text { Marrow }\end{array}$ & Jadad & 6 \\
\hline Zhao & 2012 & RCT & China & $53 / 47$ & 33.25 & 97 & $\begin{array}{l}\text { Control: CD } \\
\text { Trial: } C D+\text { Marrow }\end{array}$ & Jadad & 6 \\
\hline Pepke & 2016 & $\mathrm{RCT}$ & German & $21 / 3$ & 44.4 & 25 & $\begin{array}{l}\text { Control: CD } \\
\text { Trial: CD+Marrow }\end{array}$ & Jadad & 5 \\
\hline Zhang HJ & 2010 & Case-control & China & $20 / 12$ & 36.3 & 39 & $\begin{array}{l}\text { Control: CD } \\
\text { Trial: } C D+\text { Marrow }\end{array}$ & NOS & 8 \\
\hline Zhuo NQ & 2012 & Case-control & China & $16 / 12$ & 31.9 & 33 & $\begin{array}{l}\text { Control: } C D \\
\text { Trial: } C D+A . B\end{array}$ & NOS & 9 \\
\hline Guo HS & 2018 & Case-control & China & $56 / 20$ & 44.32 & 76 & $\begin{array}{l}\text { Control: } C D \\
\text { Trial: } C D+A \cdot B\end{array}$ & NOS & 9 \\
\hline Warner & 1987 & Case series & USA & $13 / 12$ & 38 & 39 & $C D$ & NICE & 6 \\
\hline Tooke & 1988 & Case series & USA & $14 / 19$ & 40 & 45 & $C D$ & NICE & 6 \\
\hline Lausten & 1990 & Case series & Denmark & $24 / 3$ & 40 & 29 & $C D$ & NICE & 7 \\
\hline Learmonth & 1990 & Case series & South Africa & $21 / 11$ & 37 & 41 & $C D$ & NICE & 5 \\
\hline Fairbank & 1994 & Case series & USA & $45 / 45$ & 40 & 128 & $C D$ & $\mathrm{NICE}$ & 6 \\
\hline Smith & 1995 & Case series & USA & $59 / 33$ & 41 & 114 & $C D$ & NICE & 6 \\
\hline Markel & 1996 & Case series & USA & $12 / 33$ & 38.6 & 54 & $C D$ & NICE & 6 \\
\hline Mont & 1997 & Case series & USA & $22 / 28$ & 34 & 79 & $C D$ & NICE & 5 \\
\hline Powell & 1997 & Case series & USA & $10 / 12$ & 35 & 34 & $C D$ & NICE & 6 \\
\hline lorio & 1998 & Case series & USA & NA & 40.8 & 33 & $C D$ & NICE & 5 \\
\hline Bozic & 1999 & Case series & USA & $21 / 13$ & 38 & 54 & $C D$ & NICE & 6 \\
\hline Steinberg & 2001 & Case series & USA & $123 / 85$ & 37 & 312 & $C D+A \cdot B$ & $\mathrm{NICE}$ & 5 \\
\hline Hernigou & 2002 & Case series & USA & $75 / 41$ & 31 & 189 & $\mathrm{CD}+$ Marrow & NICE & 6 \\
\hline Lieberman & 2004 & Case series & USA & $6 / 9$ & 47 & 17 & $C D$ & NICE & 5 \\
\hline Belmar & 2004 & Case series & USA & NA & NA & 302 & $C D$ & NICE & 5 \\
\hline Song & 2007 & Case series & South Korea & $120 / 16$ & 36.1 & 163 & $C D$ & NICE & 6 \\
\hline Li YP & 2007 & Case series & China & $19 / 6$ & 37.2 & 36 & $C D+A \cdot B$ & NICE & 5 \\
\hline Ji WF & 2008 & Case series & China & $71 / 16$ & 47 & 103 & $\mathrm{CD}+$ Marrow & NICE & 5 \\
\hline Xu WH & 2009 & Case series & China & $26 / 14$ & 35.6 & 42 & $C D+A \cdot B$ & $\mathrm{NICE}$ & 5 \\
\hline Wang & 2010 & Case series & China & $36 / 9$ & 37.5 & 59 & $\mathrm{CD}+$ Marrow & NICE & 5 \\
\hline Cao B & 2010 & Case series & China & $37 / 18$ & 39.8 & 61 & $C D+A \cdot B$ & $\mathrm{NICE}$ & 5 \\
\hline Yang J & 2010 & Case series & China & $50 / 5$ & 35 & 85 & $C D$ & NICE & 5 \\
\hline Zhao Y & 2011 & Case series & China & $16 / 6$ & Range (16-51) & 25 & $C D$ & NICE & 6 \\
\hline Chotivichit & 2012 & Case series & Thailand & $3 / 7$ & 36.18 & 11 & $\mathrm{CD}+$ Marrow & NICE & 6 \\
\hline Chotivichit & 2014 & Case series & Thailand & $18 / 14$ & 31.9 & 34 & $\mathrm{CD}+$ Marrow & NICE & 6 \\
\hline Chen XT & 2015 & Case series & China & $31 / 19$ & 36.2 & 58 & $C D+A \cdot B$ & NICE & 6 \\
\hline
\end{tabular}

Note: $N A$ not available, $C D$ core decompression, $C D+$ Marrow core decompression combined with autologous bone marrow, $C D+A . B$ core decompression combined with autologous bone, NICE National Institute for Clinical Excellence, NOS Newcastle-Ottawa Scale

Among the 32 studies using $\mathrm{CD}, \mathrm{CD}+$ Marrow, and $\mathrm{CD}+\mathrm{A} . \mathrm{B}$ to treat $\mathrm{ONFH}$, a total of 2441 hips were pooled into the meta-analysis on the success rate of different treatment methods, the control group and the experimental group of the case-control study and the RCT study were respectively considered as two groups of studies. The overall ES was 0.65 (95\% CI, 0.60-0.71). In subgroup analysis, the
ES and 95\% CI were calculated as 0.57 (95\% CI, 0.50-0.61), 0.74 (95\% CI, 0.66-0.83), and 0.81 (95\% CI, 0.69-0.92) in $\mathrm{CD}, \mathrm{CD}+$ Marrow, and CD+A.B subgroup, respectively, as shown in Fig. 5. Moreover, the differences between the 3 subgroups were statistically significant $(P<0.05)$.

In order to clarify the differences between the three treatment methods, we performed an $X^{2}$ test on the success 
Table 2 Clinical outcomes of included studies

\begin{tabular}{|c|c|c|c|c|c|c|c|c|}
\hline Author & Year & Therapies & Hips & $\begin{array}{l}\text { Hips to } \\
\text { THA }\end{array}$ & $\begin{array}{l}\text { Hips with } \\
\text { RP }\end{array}$ & $\begin{array}{l}\text { Staging } \\
\text { methods }\end{array}$ & Complications & $\begin{array}{l}\text { Follow-up } \\
\text { (month) }\end{array}$ \\
\hline Gangji & 2011 & $\begin{array}{l}\text { Control: CD } \\
\text { Trial: } \\
\text { CD+Marrow }\end{array}$ & $\begin{array}{l}\text { Control: } \\
11 \\
\text { Trial: } 13\end{array}$ & $\begin{array}{l}\text { Control: } 3 \\
\text { Trial: } 2\end{array}$ & $\begin{array}{l}\text { Control: } 8 \\
\text { Trial: } 3\end{array}$ & ARCO & $\begin{array}{l}\text { Pain: } 4 \\
\text { Infection: } 1\end{array}$ & 60 \\
\hline Zhao & 2012 & $\begin{array}{l}\text { Control: CD } \\
\text { Trial: } \\
\text { CD+Marrow }\end{array}$ & $\begin{array}{l}\text { Control: } \\
44 \\
\text { Trial: } 53\end{array}$ & $\begin{array}{l}\text { Control: } 5 \\
\text { Trial: } 2\end{array}$ & $\begin{array}{l}\text { Control: } 10 \\
\text { Trial: } 2\end{array}$ & ARCO & None & 60 \\
\hline Pepke & 2016 & $\begin{array}{l}\text { Control: CD } \\
\text { Trial: } \\
\text { CD+Marrow }\end{array}$ & $\begin{array}{l}\text { Control: } \\
14 \\
\text { Trial: } 11\end{array}$ & $\begin{array}{l}\text { Control: } 6 \\
\text { Trial: } 4\end{array}$ & $\begin{array}{l}\text { Control: } 6 \\
\text { Trial: } 4\end{array}$ & ARCO & NA & 24 \\
\hline Zhang HJ & 2010 & $\begin{array}{l}\text { Control: CD } \\
\text { Trial: } \\
\text { CD+Marrow }\end{array}$ & $\begin{array}{l}\text { Control: } \\
15 \\
\text { Trial: } 24\end{array}$ & NA & $\begin{array}{l}\text { Control: } 2 \\
\text { Trial: } 1\end{array}$ & ARCO & None & 18 \\
\hline Zhuo NQ & 2012 & $\begin{array}{l}\text { Control: CD } \\
\text { Trial: } C D+A \cdot B\end{array}$ & $\begin{array}{l}\text { Control: } \\
12 \\
\text { Trial: } 21\end{array}$ & $\begin{array}{l}\text { Control: } 4 \\
\text { Trial: } 1\end{array}$ & $\begin{array}{l}\text { Control: } 4 \\
\text { Trial: } 1\end{array}$ & Ficat & None & 30 \\
\hline Guo HS & 2018 & $\begin{array}{l}\text { Control: CD } \\
\text { Trial: } C D+A \cdot B\end{array}$ & $\begin{array}{l}\text { Control: } \\
41 \\
\text { Trial: } 35\end{array}$ & NA & $\begin{array}{l}\text { Control: } 6 \\
\text { Trial: } 1\end{array}$ & Ficat & Pain: 1 & 30 \\
\hline Warner & 1987 & $C D$ & 39 & 19 & 23 & Ficat & $\begin{array}{l}\text { Fracture: } 1 \\
\text { Hematoma: } 1\end{array}$ & 16 \\
\hline Tooke & 1988 & $C D$ & 45 & 16 & 16 & Ficat & Fracture: 1 & 36 \\
\hline Lausten & 1990 & $C D$ & 29 & 15 & 11 & Ficat & Pain: 1 & 17.2 \\
\hline Learmonth & 1990 & $C D$ & 41 & 18 & 34 & Ficat & Fracture: 1 & 32 \\
\hline Fairbank & 1994 & $C D$ & 128 & 55 & 81 & Ficat & $\begin{array}{l}\text { Fracture: } 4 \\
\text { Perforation of femoral head: } 1 \\
\text { Deep venous thrombosis: } 2 \\
\text { Retained drain: } 1\end{array}$ & 132 \\
\hline Smith & 1995 & $C D$ & 114 & 64 & 81 & Ficat & $\begin{array}{l}\text { Infection: } 3 \\
\text { Fracture: } 2 \\
\text { Hematoma: } 2 \\
\text { Non-fatal pulmonary embolism: } \\
1 \\
\text { Deep venous thrombosis: } 1 \\
\text { Reflex sympathetic dystrophy: } 1\end{array}$ & 40 \\
\hline Markel & 1996 & $C D$ & 54 & 26 & NA & Ficat & $\begin{array}{l}\text { Fracture: } 2 \\
\text { Infection: } 1\end{array}$ & 27.1 \\
\hline Mont & 1997 & $C D$ & 79 & 37 & 37 & Ficat & NA & 144 \\
\hline Powell & 1997 & $C D$ & 34 & 6 & 9 & Ficat & None & 48 \\
\hline lorio & 1998 & $C D$ & 33 & 11 & 17 & Ficat & NA & 60 \\
\hline Bozic & 1999 & $C D$ & 54 & 28 & 34 & Ficat & $\begin{array}{l}\text { Fracture: } 1 \\
\text { Hematoma: } 1\end{array}$ & 97 \\
\hline Steinberg & 2001 & $C D+A \cdot B$ & 312 & 113 & 113 & UPSS & NA & 48 \\
\hline Hernigou & 2002 & CD+Marrow & 189 & 34 & 52 & Ficat & $\begin{array}{l}\text { Pain: } 1 \\
\text { Pneumonia: } 1 \\
\text { Alloimmunization: } 1\end{array}$ & 84 \\
\hline Lieberman & 2004 & $C D$ & 17 & 3 & 3 & Ficat & Pain: 4 & 53 \\
\hline Belmar & 2004 & $C D$ & 302 & 113 & NA & UPSS & NA & 46 \\
\hline Song & 2007 & $C D$ & 163 & 50 & NA & Ficat & $\begin{array}{l}\text { Heterotopic ossifications: } 23 \\
\text { Fracture: } 1\end{array}$ & 87 \\
\hline Li YP & 2007 & $C D+A \cdot B$ & 36 & 4 & 4 & ARCO & NA & 23.4 \\
\hline Ji WF & 2008 & CD+Marrow & 103 & NA & NA & UPSS & None & 26 \\
\hline Xu WH & 2009 & $C D+A \cdot B$ & 42 & NA & NA & Ficat & None & 38 \\
\hline Wang & 2010 & $C D+$ Marrow & 59 & 7 & 14 & ARCO & NA & 27.6 \\
\hline
\end{tabular}


Table 2 Clinical outcomes of included studies (Continued)

\begin{tabular}{|c|c|c|c|c|c|c|c|c|}
\hline Author & Year & Therapies & Hips & $\begin{array}{l}\text { Hips to } \\
\text { THA }\end{array}$ & $\begin{array}{l}\text { Hips with } \\
\text { RP }\end{array}$ & $\begin{array}{l}\text { Staging } \\
\text { methods }\end{array}$ & Complications & $\begin{array}{l}\text { Follow-up } \\
\text { (month) }\end{array}$ \\
\hline Cao B & 2010 & $C D+A \cdot B$ & 61 & NA & 22 & Ficat & NA & 26.4 \\
\hline Yang J & 2010 & $C D$ & 85 & 6 & 19 & UPSS & None & 57.6 \\
\hline Zhao Y & 2011 & $C D$ & 25 & 2 & NA & Ficat & NA & 73 \\
\hline Chotivichit & 2012 & CD+Marrow & 11 & 2 & 8 & Ficat & NA & 42.6 \\
\hline Chotivichit & 2014 & CD+Marrow & 34 & 10 & 9 & Ficat & Pain: 4 & 25.8 \\
\hline Chen XT & 2015 & $C D+A \cdot B$ & 58 & 11 & 11 & ARCO & NA & 34.05 \\
\hline
\end{tabular}

Note: $N A$ not available, $C D$ core decompression, $C D+$ Marrow core decompression combined with autologous bone marrow, $C D+A . B$ core decompression combined with autologous bone, $T H A$ total hip replacement, $R P$ radiographic progression

rate. Statistical results display: success rate of $C D$ and success rate of $C D+$ Marrow, the difference is statistically significant $\left(X^{2}=53.236, P<0.05\right)$; success rate of $\mathrm{CD}$ and success rate of $C D+A . B$, the difference was statistically significant $\left(X^{2}=36.245, \quad P<0.05\right)$; and success rate of $\mathrm{CD}+$ Marrow and success rate of $\mathrm{CD}+\mathrm{A} . \mathrm{B}$, the difference is statistically significant $\left(X^{2}=2.067, P=0.151\right)$.

\section{Rate of conversion to THA}

Conversion to THA was recorded in 27 studies [5, 8-25, 28, 29, 31-36] using CD, CD+Marrow and CD+A.B for treatment of ONFH, a total of 2120 hips were pooled into the meta-analysis on rate of conversion to THA, the control group and the experimental group of the casecontrol study and the RCT study were respectively considered as two groups of studies. A conversion to THA was seen in 677 hips, which presented an overall ES of 0.28 (95\% CI, 0.22-0.34). In subgroup analysis, the ES and $95 \% \mathrm{CI}$ were calculated as 0.34 (95\% CI, 0.26-0.42), 0.16 (95\% CI, 0.08-0.24), and 0.18 (95\% CI, 0.02-0.34) in $\mathrm{CD}, \mathrm{CD}+$ Marrow, and $\mathrm{CD}+\mathrm{A} . \mathrm{B}$ subgroup, respectively, as shown in Fig. 6. Furthermore, the differences between the 3 subgroups were statistically significant $(P<0.05)$.

In order to clarify the differences between the three treatment methods, we performed an $X^{2}$ test on the rate of conversion to THA. Statistical results display: CD and $\mathrm{CD}+$ Marrow rate of conversion to THA, the difference is statistically significant $\left(X^{2}=54.556, P<0.05\right), C D$ and $\mathrm{CD}+\mathrm{A} . \mathrm{B}$ rate of conversion to THA, the difference is statistically significant $\left(X^{2}=6.614, P<0.05\right)$, CD+Marrow and $C D+A . B$ rate of conversion to THA, the difference is statistically significant $\left(X^{2}=20.565, P<0.05\right)$.

\section{Rate of radiographic progression}

Radiographic progression was recorded in 26 studies [5, 8-10, 12-19, 21-25, 27-29, 32, 33, 35-38] using CD, CD+Marrow and CD+A.B for treatment of ONFH, a total of 1752 hips were pooled into the meta-analysis on rate of radiographic progression, the control group and the experimental group of the case-control study and the RCT study were respectively considered as two groups of studies. A radiographic progression was seen in 646 hips, which presented an overall ES of 0.35 (95\% CI, 0.27-0.42). In subgroup analysis, the ES and 95\% CI were calculated as 0.43 (95\% CI, 0.32-0.54), 0.27 (95\% CI, 0.17-0.32), and 0.18 (95\% CI, 0.02-0.35) in CD, $\mathrm{CD}+$ Marrow, and $\mathrm{CD}+\mathrm{A} . \mathrm{B}$ subgroup, respectively, as shown in Fig. 7. Furthermore, the differences between the 3 subgroups were statistically significant $(P<0.05)$.

In order to clarify the differences between the three treatment methods, we performed an $X^{2}$ test on the rate of radiographic progression. Statistical results display $\mathrm{CD}$ and $\mathrm{CD}+$ Marrow rate of radiographic progression, the difference is statistically significant $\left(X^{2}=66.406, P<\right.$ $0.05)$; $C D$ and $C D+A . B$ rate of radiographic progression, the difference was statistically significant $\left(X^{2}=47.894\right.$, $P<0.05)$; $C D+$ Marrow and $C D+A . B$ rate of radiographic progression, the difference is statistically significant $\left(X^{2}=3.420, P=0.064\right)$.

\section{Discussion}

The core decompression can be targeted to scrape the lesion to the peripheral wall of the bone, which is obviously oozing, that is, close to the normal bone tissue, effectively improving the blood circulation of the bone bed, facilitating the growth of the blood vessel along the tunnel into the femoral head and promoting the repair of the femoral head $[39,40]$. Common surgical procedures include core decompression, core decompression plus autologous bone marrow and core decompression plus autologous bone grafting. This study has systematically reviewed the efficacy of core decompression therapy for ONFH. We analyzed the etiology factors, the type of complications and the number of hips, the influence of different preoperative staging on the prognosis, the success rate of different treatment methods, the rate of conversion to THA, and the rate of radiographic progression.

Twenty-nine studies (2095 hips) clearly documented the etiologic factors, mainly steroid and alcohol. However, each study was unable to provide the final 


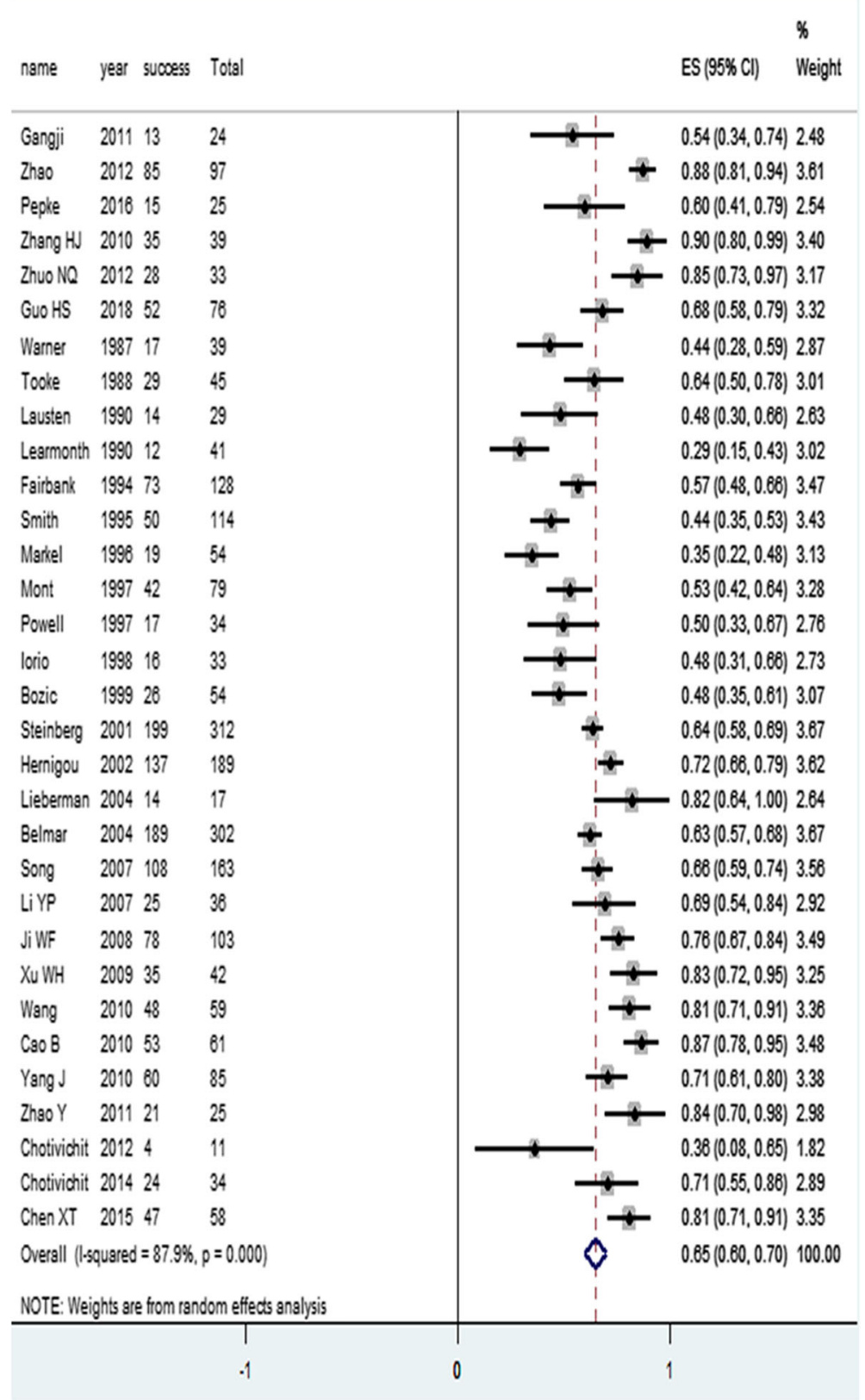

Fig. 2 Overall success rate meta-analysis

treatment outcome for each of the etiologic factors, and we were unable to analyze the impact of the etiologic factors on the prognosis. Review literature found that alcohol and steroid are common causes of ONFH [41, 42], drinking alcohol and applying corticosteroids can cause lipid metabolism disorder [43, 44]. It leads to an increase in the volume of fat cells, fat embolism, etc. which plays an important role in the whole process of femoral head necrosis [45]. From an etiological perspective, it is an important measure to stay away from these risk factors while treating.
Complications were described in 21 studies (1440 hips). Due to the lack of information, there was no detailed statistical analysis of complications, only a rough calculation of the overall complication rate $(4.79 \% 69 / 1440)$. Complications were described in 21 studies.

Of the 32 studies included, a total of three staging criteria were used, Ficat, ARCO, and UPSS, respectively. Considering the effect of the number of studies and the sample size on the results, only compare the success rates of the included Ficat I, II, and III cases. The success rate was I $>$ II $>$ III, and the difference was statistically 


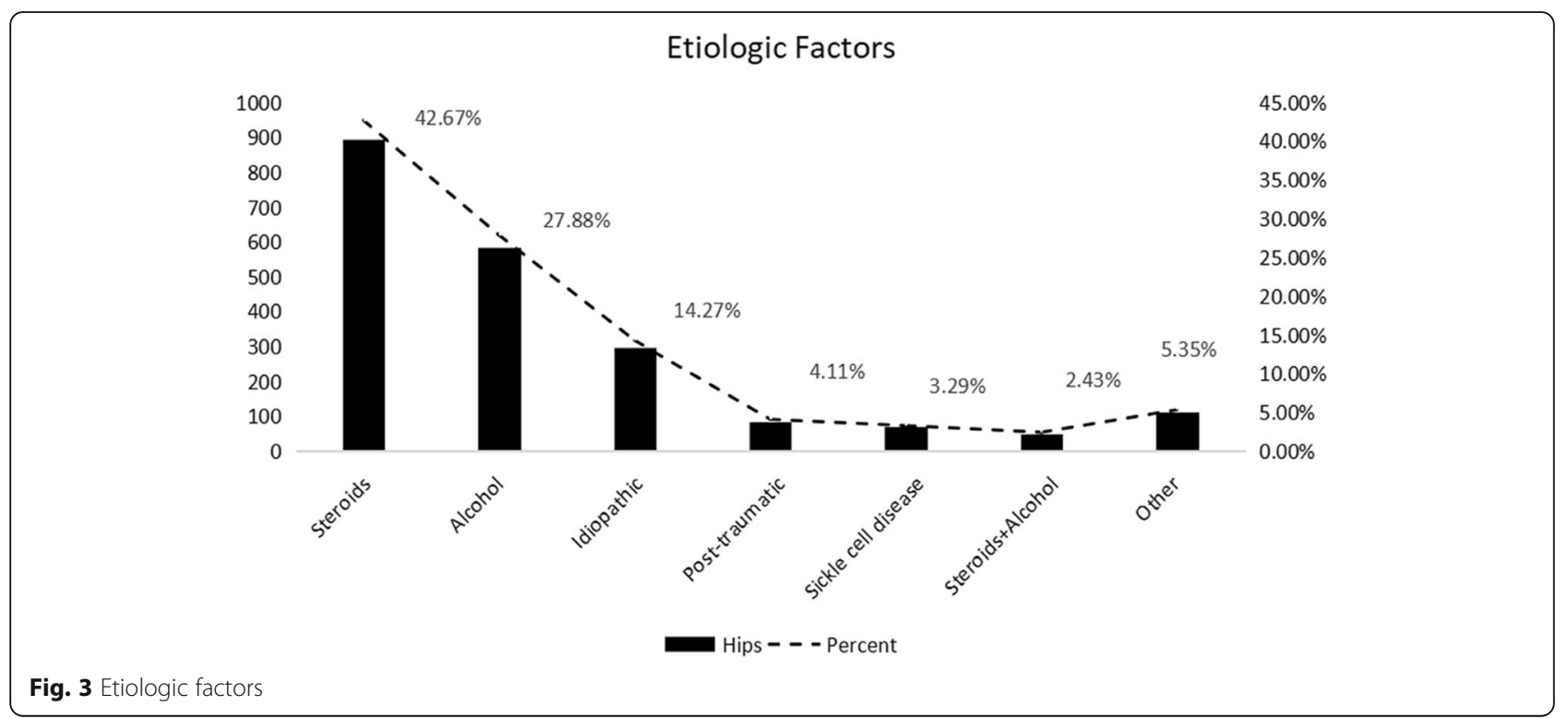

significant. It is proved that preoperative staging is an important factor affecting postoperative, and the success rate of stage III is only $27.44 \%$. The authors believe that CD should be considered carefully for cases of stage III. This procedure is especially suitable for young patients with early femoral head necrosis, for delaying or avoiding total hip replacement is of great significance [10, 19, 29, 32].

There are three treatment methods in the selected articles, $\mathrm{CD}, \mathrm{CD}+$ Marrow, and CD+A.B. The three treatment methods have different success rates. Further statistical analysis shows that composite bone marrow or autologous bone can significantly improve the success rate. The success rate of $\mathrm{CD}+$ Marrow $(74.0 \%)$ and the success rate of
CD+A.B (81.0\%) are both higher than the overall success rate $(65.0 \%)$, and $C D+A . B$ has the highest success rate. In addition, in the study using $C D+A . B$, the success rate of only one study [5] is lower than the overall success rate.

The authors noted that in addition to the above methods, there were reports of core decompression with vascular pedicle bone graft, core decompression combined with bone debridement, and core decompression combined with tantalum rod implantation, all of which achieved satisfactory clinical results $[46,47]$.

Twenty-seven studies (2120 hips) detail the conversion to THA under different treatments. Both $C D+A . B$ and $C D+$ Marrow significantly reduce the

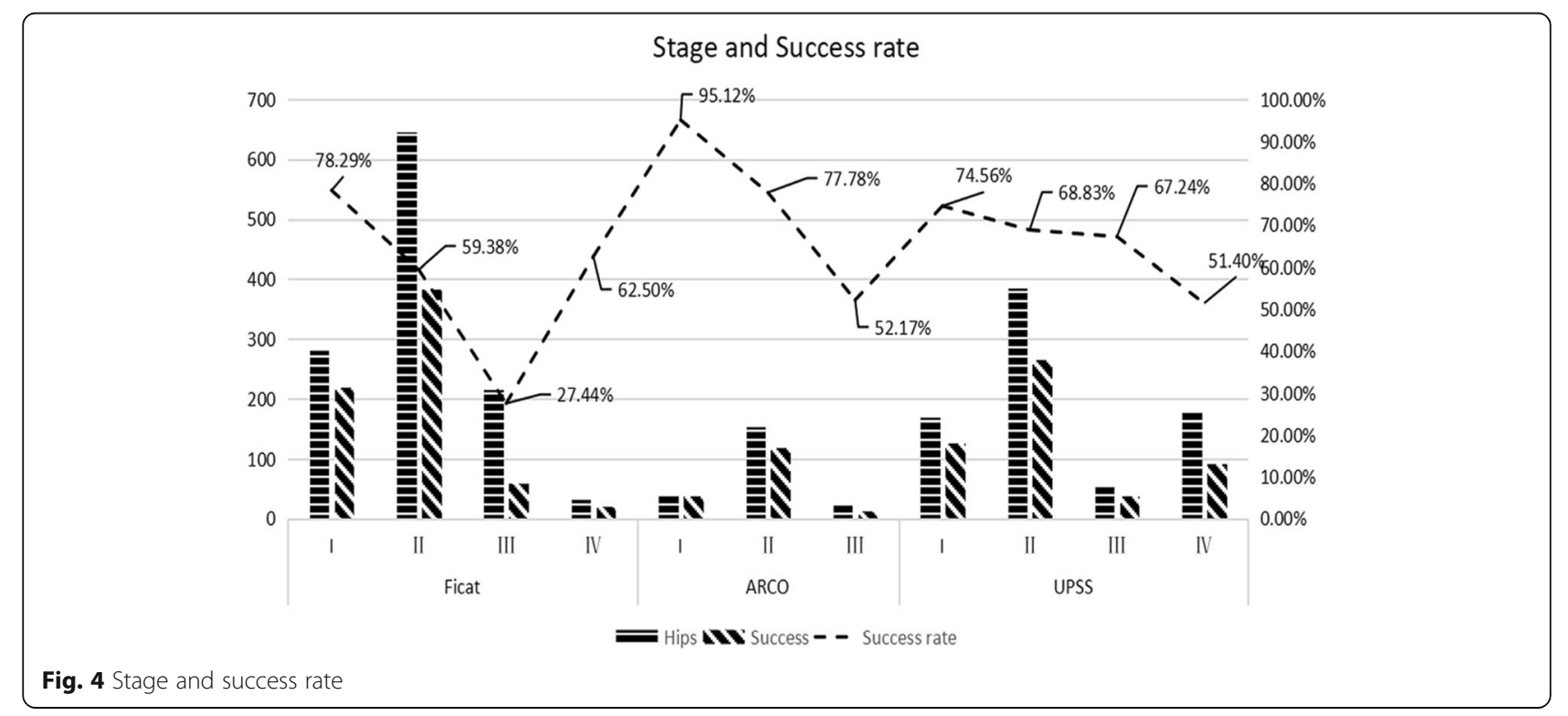




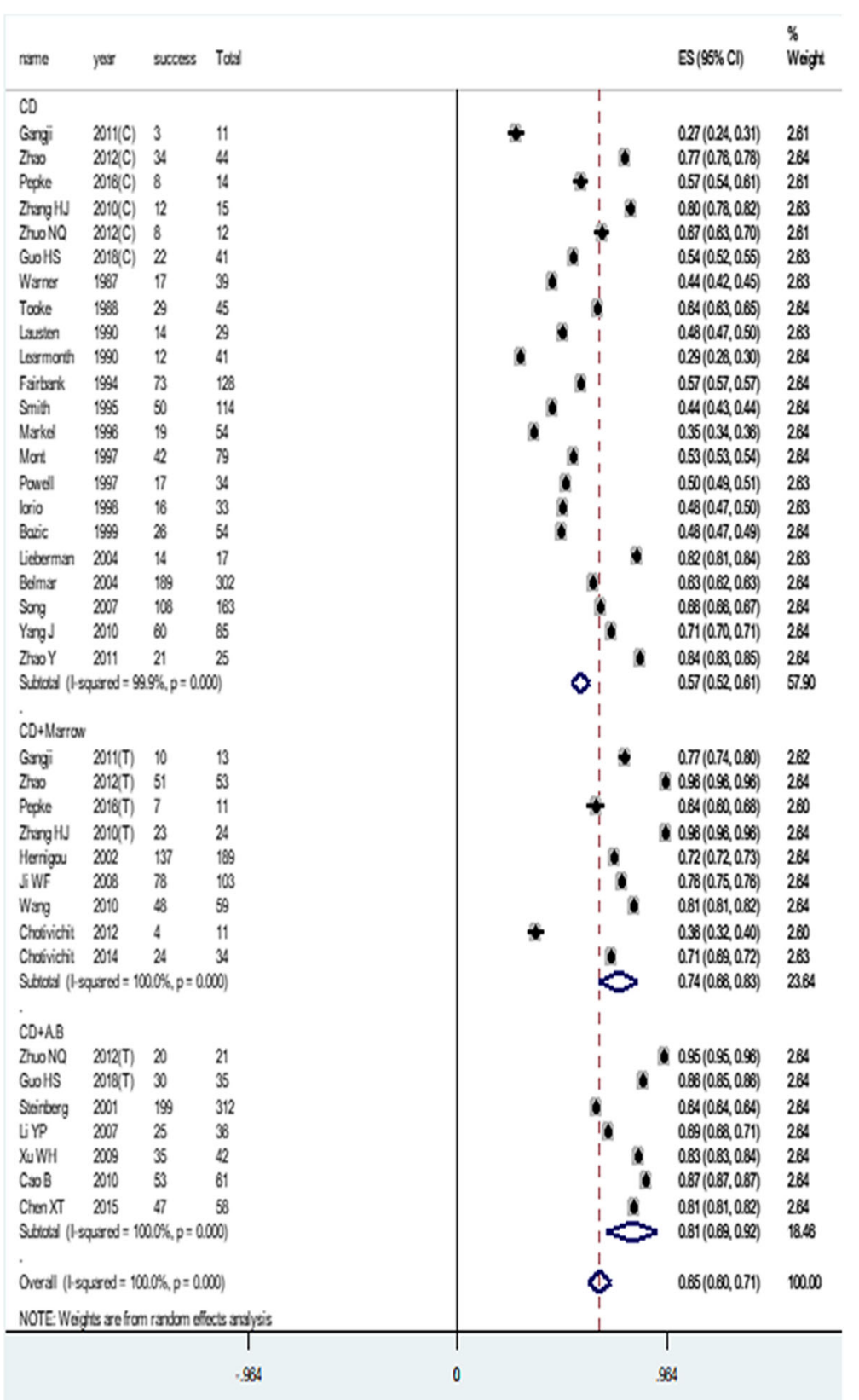

Fig. 5 Meta-analysis of success rates for different treatments (C, control group; T, trial group)

rate of conversion to THA compared to CD. Twenty-six studies (1752 hips) detail the radiographic progression under different treatments. Both methods significantly reduce the rate of radiographic progression compared to $\mathrm{CD}$. These two results are also consistent with the success rate of three treatment methods.

Three studies [27, 33, 36] added additional bone morphogenetic proteins (BMP) during treatment, which caught our interest in this substance. Exogenous BMP has a positive effect on the treatment of femoral head necrosis [48]. BMP is widely present in the bone matrix, which induces osteogenic cells in normal bone tissue and generates bone and cartilage tissue in bone and surrounding soft tissues [49]. Zhuo et al. [36] believe that the addition of BMP can promote the repair of the femoral head, cure, or delay the progression of the disease.

Two studies [26, 30] used graft materials of allogeneic bone composite autologous bone during the treatment, which is also the current development trend of bone transplantation. Autologous bone provides the 


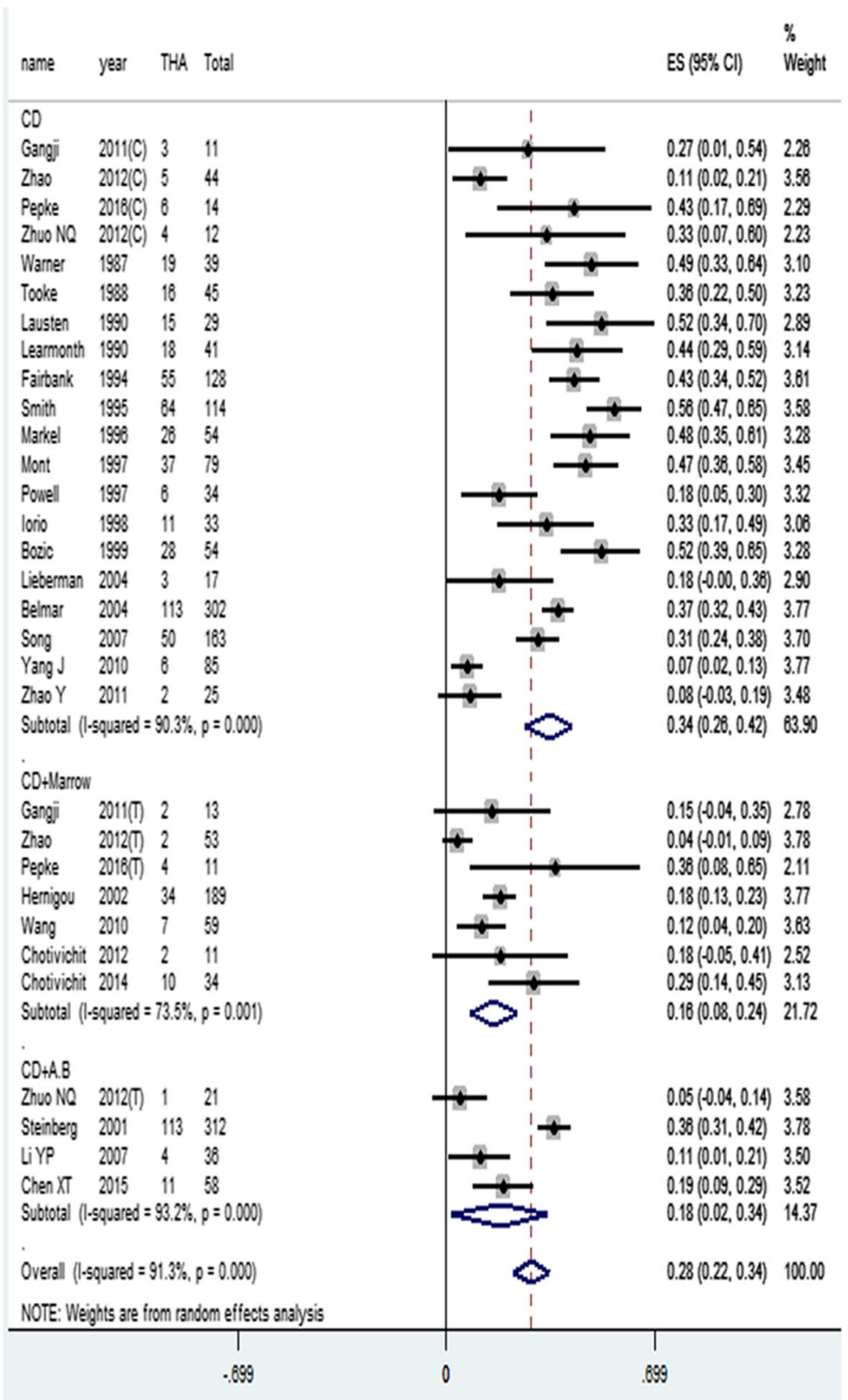

Fig. 6 Conversion THA rate meta-analysis (C, control group; T, trial group)

best osteogenic and osteoinductive capacity without immune rejection [50]. However, its defects are also very obvious, such as prolonged operation time, increased trauma area of the patient, insufficient bone supply and many complications in the donor site [51]. The use of allogeneic bone can avoid the defects of autologous bone, and its osteogenic and osteoinductive ability is also widely recognized. With the deepening of scientific research, the problem of immune rejection and disease transmission in allogeneic transplantation is also a very good solution $[52,53]$. The prospect of application of allogeneic bone in the treatment of femoral head necrosis is worth looking forward to.

\section{Limitation}

The current meta-analysis has certain limitations. First, there were only three RCTs in these studies, which led to a lower than expected level of evidence for our comprehensive comparison. Second, each study has different definitions of success, and assessing the diversity of standards will inevitably lead to 


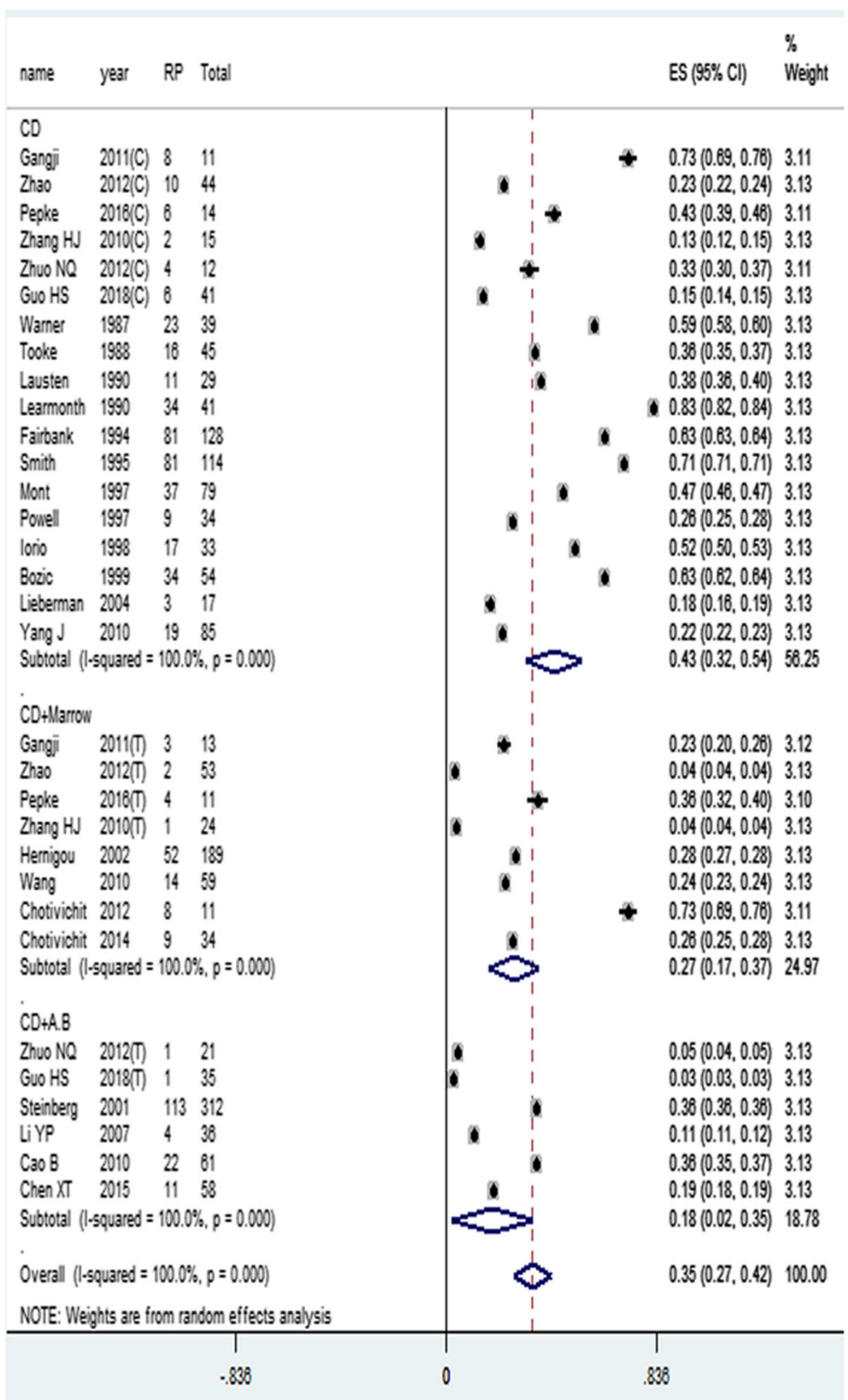

Fig. 7 Rate of radiographic progression meta-analysis (C, control group; $T$, trial group)

bias in the final combined results. Third, some of the research lacks some important information, for example, etiology, complications, and postoperative rehabilitation of patients, this will lead to some factors that can only be used for simple calculation and analysis, and statistical tests cannot be performed. Finally, some innovative treatments are not included in the study, and the emergence of new methods requires a period of case accumulation in order to get a larger sample, which requires constant updating of the study in the future.

\section{Conclusion}

Core decompression is an effective and safe method of treating ONFH. The combined use of autologous bone or bone marrow can increase the success rate. For advanced femoral head necrosis, the use of $C D$ should be cautious. High-quality randomized controlled trials and prospective studies will be necessary to clarify the effects of different etiology factors, treatments, and postoperative rehabilitation. Until then, the surgeon can choose core decompression to treat ONFH depending on the patient's condition. 


\section{Supplementary information}

Supplementary information accompanies this paper at https://doi.org/10. 1186/s13018-019-1359-7.

Additional file 1: The searching strategies used in platforms of PubMed and EMBASE. (12.9 KB)

\section{Abbreviations}

ARCO: Association Research Circulation Osseous; BMP: Bone morphogenetic proteins; CD Autologous bone: Core decompression combined with autologous bone; CD Marrow: Core decompression combined with autologous bone marrow; CD: Core decompression; ES: Effect size; HHS: Harris hip score; NICE: National Institute for Clinical Excellence; NOS: Newcastle-Ottawa Scale; ONFH: Osteonecrosis of the femoral head; RP: Radiographic progression; THA: Total hip replacement; UPSS: University of Pennsylvania system for staging avascular necrosis

\section{Acknowledgments}

I would like to express my special thanks to my partners for the encouragement and support they gave me during my study. Thanks to my girlfriend, Miss Sun, for her support for my life and research.

\section{Authors' contributions}

$\mathrm{KCH}$ contributed to the methodology, validation, formal analysis, investigation, data curation, writing of the original draft, writing-reviewing and editing, project administration. XGY, and JTF contributed to the investigation, writing-reviewing and editing. FW contributed to the methodology, validation, investigation, writing-reviewing and editing. $\mathrm{LY}$ and $\mathrm{HZ}$ contributed to the conceptualization, methodology, validation, formal analysis, investigation, data curation, writing original draft, writing-reviewing, and editing, project administration, and supervision. YCH contributed to the conceptualization, methodology, validation, investigation, writing-reviewing and editing. All authors read and approved the final manuscript.

\section{Funding}

This research did not receive any specific grant from funding agencies in the public, commercial, or not-for-profit sectors.

\section{Availability of data and materials}

The authors declare that all the data supporting the findings of this study are available within the article and its supplementary information files.

\section{Ethics approval and consent to participate}

Not applicable

\section{Consent for publication}

Not applicable

\section{Competing interests}

The authors declare that they have no competing interests.

\section{Author details}

'Department of Orthopedic Oncology, Tianjin Hospital, Tianjin 300211, China

${ }^{2}$ Tianjin Medical University, Tianjin 300070, China

\section{Received: 11 June 2019 Accepted: 3 September 2019}

Published online: 11 September 2019

\section{References}

1. Lieberman JR, Berry DJ, Aaron RK, et al. Osteonecrosis of the hip: management in the twenty-first century. J Bone Joint Surg (Am Vol). 2002; 84(52):337-55

2. Mont MA, Jones LC, Hungerford DS. Nontraumatic osteonecrosis of the femoral head: ten years later. J Bone Joint Surg (Am Vol). 2006;88(5):111732

3. Mont MA, Ragland PS, Etienne G. Core decompression of the femoral head for osteonecrosis using percutaneous multiple small-diameter drilling. Clin Orthop Relat Res. 2004;429:131-8.
4. Zhang HJ, Liu YW, Du Z-Q, et al. Therapeutic effect of minimally invasive decompression combined with impaction bone grafting on osteonecrosis of the femoral head. Eur J Orthop Surg Traumatol. 2013;23(8):913-9.

5. Steinberg ME, Larcom PG, Strafford B, et al. Core decompression with bone grafting for osteonecrosis of the femoral head. Clin Orthop Relat Res. 2001;386:71-8.

6. Yu X, Zhang D, Chen X, et al. Effectiveness of various hip preservation treatments for non-traumatic osteonecrosis of the femoral head: a network meta-analysis of randomized controlled trials. J Orthop Sci. 2017;23(2):1-9.

7. Shibing X, Lei Z, Hongting J, et al. Autologous stem cells combined core decompression for treatment of avascular necrosis of the femoral head: a systematic meta-analysis. Biomed Res Int. 2017;2017:1-11.

8. Gangji V, De Maertelaer V, Hauzeur JP. Autologous bone marrow cell implantation in the treatment of non-traumatic osteonecrosis of the femoral head: five year follow-up of a prospective controlled study. Bone. 2011:49(5):1005-9.

9. Pepke W, Kasten P, Beckmann NA, et al. Core decompression and autologous bone marrow concentrate for treatment of femoral head osteonecrosis: a randomized prospective study. Orthop Rev (Pavia). 2016; 8(1):6162.

10. Zhao D, Cui D, Wang B, et al. Treatment of early stage osteonecrosis of the femoral head with autologous implantation of bone marrow-derived and cultured mesenchymal stem cells. Bone. 2012;50(1):325-30.

11. Belmar CJ, Steinberg ME, Hartman-Sloan KM. Does pain predict outcome in hips with osteonecrosis? Clin Orthop Relat Res. 2004;425:158-62.

12. Bozic KJ, Zurakowski D, Thornhill TS. Survivorship analysis of hips treated with core decompression for nontraumatic osteonecrosis of the femoral head. J Bone Joint Surg Am Vol. 1999;81(2):200-9.

13. Chotivichit A, Korwutthikulrangsri E, Auewarakul C, et al. Core decompression and concentrated autologous bone marrow injection for treatment of osteonecrosis of the femoral head. J Med Assoc Thai. 2012:95 Suppl 9(supplement 9):S14-20.

14. Chotivichit A, Korwutthikulrangsri E, Pornrattanamaneewong C, et al. Core decompression with bone marrow injection for the treatment of femoral head osteonecrosis. J Med Assoc Thai. 2014:97(Suppl9):S139-43.

15. Fairbank $A C$, Bhatia $D$, Jinnah $\mathrm{RH}$, et al. Long-term results of core decompression for ischemic necrosis of the femoral head. J Bone Joint Surg Br Vol. 1995;77(1):42-9.

16. Hernigou P, Beaujean F. Treatment of osteonecrosis with autologous bone marrow grafting. Clin Orthop Relat Res. 2002;405:14-23.

17. Iorio R, Healy WL, Abramowitz AJ, et al. Clinical outcome and survivorship analysis of core decompression for early osteonecrosis of the femoral head. J Arthroplasty. 1998;13(1):34.

18. Lausten GS, Mathiesen B. Core decompression for femoral head necrosis: prospective study of 28 patients. Acta Orthop Scand. 1991;61(6):507-11.

19. Learmonth ID, Maloon S, Dall G. Core decompression for early atraumatic osteonecrosis of the femoral head. J Bone Joint Surg Br Vol. 1990;72-B(3): 387-90.

20. Markel DC, Miskovsky C, Sculco TP, et al. Core decompression for osteonecrosis of the femoral head. Clin Orthop Relat Res. 1996:323(323): 226-33.

21. Mont MA, Fairbank AC, et al. Core decompression for osteonecrosis of the femoral head in systemic lupus erythematosus. Clin Orthop Relat Res. 1997; 334(334):91-7.

22. Powell ET, Lanzer WL, Mankey MG. Core decompression for early osteonecrosis of the hip in high-risk patients. Clin Orthop Relat Res. 1997; 335(335):181-9.

23. Smith SW, Fehring TK, Griffin WL, et al. Core decompression of the Osteonecrotic femoral head. J Bone Joint Surg. 1995;77(5):674-80.

24. Tooke SMT, Nugent PJ, Bassett LW, et al. Results of core decompression for femoral head osteonecrosis. Clin Orthop Relat Res. 1988;NA(228):99-104.

25. Warner JJP, Philip JH, Brodsky GL, et al. Studies of nontraumatic osteonecrosis: the role of core decompression in the treatment of nontraumatic osteonecrosis of the femoral head. Clin Orthop Relat Res. 1987:225(225):104-27.

26. Feng JW, Hang DW, Chuan MZ, et al. Three-tunnels core decompression with implantation of bone marrow stromal cells (bMSCs) and decalcified bone matrix (DBM) for the treatment of early femoral head necrosis. China Orthop Trauma. 2008:21(10):776-8.

27. Bin $C$, Hui $L Y$, Ying $W$, et al. Clinical application of minimally invasive core decompression combined with impaction bone grafting to the treatment of femoral head necrosis. China J Orthop Trauma. 2010;23(2):111-3. 
28. Yaping L, Qingan Z, Haiping X. Treatment for osteonecrosis of femoral head with morselized periosteum and bone grafting after arthroscopic core decompression. Chin J Bone Joint Inj. 2007;22(11):902-4.

29. Jing $Y$, Pengde K, Bin S. Treatment of early stage osteonecrosis of the femoral head with multiple small-diameter drilling core decompression. Chin J Orthop. 2010;30(1):58-61.

30. Weihua $X$, Shuhua $Y$, Baoxing $L$, et al. Allogeneic cortical bone cage support combining with autologous cancellous bone grafting for managing femoral head necrosis. Chin J Reparative Reconstr Surg. 2009;23(5):527-9.

31. Yong Z, Songti C. Closed core decompression for aseptic necrosis of femoral head: 22 cases of clinical summary. Chin J Inj Repair Wound Healing. 2011;6(3):427-8.

32. Chen XT, Tan XY, Liu YW, et al. Application of minimally invasive, decompression bone graft implantation combined with metal trabecular bone reconstruction system for early stage osteonecrosis of femoral head. China J Orthop Traumatol. 2015;28(5):422-5.

33. Lieberman JR, Conduah A, Urist MR. Treatment of osteonecrosis of the femoral head with core decompression and human bone morphogenetic protein. Clin Orthop Relat Res. 2004:429:139-45.

34. Song WS, Yoo JJ, Kim YM, et al. Results of multiple drilling compared with those of conventional methods of core decompression. Clin Orthop Relat Res. 2007;454:139-46.

35. Wang BL, Sun W, Shi ZC, et al. Treatment of nontraumatic osteonecrosis of the femoral head with the implantation of core decompression and concentrated autologous bone marrow containing mononuclear cells. Arch Orthop Trauma Surg. 2010;130(7):859-65.

36. Naiqiang Z, Yongxian W, Xiaobo L, et al. Comprehensive management of early stage avascular necrosis of femoral head by arthroscopic minimally invasive surgery. Chin J Reparative Reconstr Surg. 2012;26(9):1041-4.

37. Hongjun Z, Shutu G, Yongcheng H. Core decompression combined with implantation of autologous bone marrow stem cells for early stage osteonecrosis of the femoral head: a primary report. Chin J Orthop. 2010;30(1):48-52.

38. Guo HS, Tian YJ, Liu G, et al. Arthroscopy-guided core decompression and bone grafting combined with selective arterial infusion for treatment of early stage avascular necrosis of femoral head. China J Orthop Trauma. 2018;31(1):56-60.

39. Rajagopal M, Balch Samora J, Ellis TJ. Efficacy of core decompression as treatment for osteonecrosis of the hip: a systematic review. Hip Int. 2012; 22(5):489-93.

40. Wei BF, Ge XH. Treatment of osteonecrosis of the femoral head with core decompression and bone grafting. Hip Int. 2011;21(2):206-10.

41. Zhang G, Qin L, Sheng $H$, et al. A novel semisynthesized small molecule icaritin reduces incidence of steroid-associated osteonecrosis with inhibition of both thrombosis and lipid-deposition in a dose-dependent manner. Bone. 2009;44(2):345-56.

42. Pengde $K$, Fuxing $P$, Bin S, et al. Lovastatin inhibits adipogenesis and prevents osteonecrosis in steroid-treated rabbits. Joint Bone Spine. 2008; 75(6):696-701

43. Vande Berg BC, Gilon R, Malghem J, et al. Correlation between baseline femoral neck marrow status and the development of femoral head osteonecrosis in corticosteroid-treated patients: a longitudinal study by MR imaging. Eur J Radiol. 2006;58(3):444-9.

44. Qin L, Zhang $\mathrm{G}$, Sheng $\mathrm{H}$, et al. Multiple bioimaging modalities in evaluation of an experimental osteonecrosis induced by a combination of lipopolysaccharide and methylprednisolone. Bone. 2006;39(4):863-71.

45. Kitajima M, Shigematsu M, Ogawa K, et al. Effects of glucocorticoid on adipocyte size in human bone marrow. Med Mol Morphol. 2007;40(3):150-6.

46. Lee MS, Hsieh PH, Chang YH, et al. Elevated intraosseous pressure in the intertrochanteric region is associated with poorer results in osteonecrosis of the femoral head treated by multiple drilling. J Bone Joint Surg Br Vol. 2008; 90-B(7):852-7.

47. Marker DR, Seyler TM, Ulrich SD, et al. Do modern techniques improve core decompression outcomes for hip osteonecrosis? Clin Orthop Relat Res. 2008;466(5):1093-103.

48. Kang P, Shen B, Yang J, et al. Repairing defect and preventing collapse of canine femoral head using titanium implant enhanced by autogenous bone graft and rhBMP-2. Connect Tissue Res. 2007:48(4):171-9.

49. Linkhart TA, Mohan S, Baylink DJ. Growth factors for bone growth and repair: IGF, TGFß and BMP. Bone. 1996;19(1):1S-12S.

50. Seebach C, Schultheiss J, Wilhelm K et al. Comparison of six bone-graft substitutes regarding to cell seeding efficiency, metabolism and growth behaviour of human mesenchymal stem cells (MSC) in vitro. Injury. 2010; 41(7):731-8.

51. Ignjatovic N, Ninkov P, Ajdukovic Z, et al. Biphasic calcium phosphate coated with poly-d,l-lactide-co-glycolide biomaterial as a bone substitute. J Eur Ceram Soc. 2007;27(2-3):1589-94.

52. Smith CA, Richardson SM, Eagle MJ, et al. The use of a novel bone allograft wash process to generate a biocompatible, mechanically stable and osteoinductive biological scaffold for use in bone tissue engineering. J Tissue Eng Regen Med. 2015;9(5):595-604.

53. Akkus $\mathrm{O}$, Rimnac CM. Fracture resistance of gamma radiation sterilized cortical bone allografts. J Orthop Res. 2001;19(5):927-34.

\section{Publisher's Note}

Springer Nature remains neutral with regard to jurisdictional claims in published maps and institutional affiliations.
Ready to submit your research? Choose BMC and benefit from:

- fast, convenient online submission

- thorough peer review by experienced researchers in your field

- rapid publication on acceptance

- support for research data, including large and complex data types

- gold Open Access which fosters wider collaboration and increased citations

- maximum visibility for your research: over $100 \mathrm{M}$ website views per year

At BMC, research is always in progress.

Learn more biomedcentral.com/submissions 